International Journal of Instruction e-ISSN: 1308-1470 • www.e-iji.net

Article submission code: 20200313053306

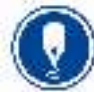

Received: 13/03/2020 Revision: 21/09/2020
April 2021 • Vol.14, No.2

p-ISSN: 1694-609X

pp. 385-404

Accepted: 13/10/2020

OnlineFirst: 26/01/2021

\title{
Exploring Crucial Factors of an Interest in STEM Career Model among Secondary School Students
}

\section{Fazilah Razali}

Dr., Senior Lecturer, Faculty of Educational Studies, Universiti Putra Malaysia, Malaysia,fazilahrazali@upm.edu.my

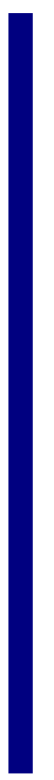

\begin{abstract}
Many countries desperately need manpower from the fields of Science, Technology, Engineering and Mathematics (STEM) to help address the country's increasingly volatile economy. Barriers to implementation are identified when students are less exposed to STEM Education goals. Therefore, this study is to determine the main factor that could influence the development of STEM career interest among secondary school learners. Thus, the objective of this study is to develop a model towards the STEM career interest formation among Form 4 science stream students in Malaysia. This study uses quantitative study and proportionate stratified random sampling method in data collection. It involved 314 students Form 4 secondary school science stream in Selangor, Malaysia. The study used three instruments to collect data, namely S-STEM and interest in STEM careers, Science Motivation Questionnaire II (SMQ II), and Parental Authority Questionnaire (PAQ). Implementing correlational analysis between factors and simultaneous regression to determine the overall contributing with huge impacts of each factor towards the formation of STEM career interest among learners with the value of standardized regression weight for the determination coefficient $\left(\mathrm{R}^{2}\right)=$ 0.64. The result of the findings shows the crucial factors in this study are accurate there are attitudes towards STEM, 21st-century skills, science motivation, and parental authority significance with the huge contribution of the cultivation of learners' STEM careers interest entirely.
\end{abstract}

Keywords: industrial needs, model, science curriculum, secondary school, stem career interest

\section{INTRODUCTION}

STEM in the education system plays a role in giving opportunities for learners to experience learning in actual career settings (Deming \& Noray, 2018). The importance of integrating STEM in the science curriculum was realized when there are demands for STEM field careers in the global job industry which are higher as compared to other careers. Aligned with the U.S Department of Commerce (2017) which emphasized that $69 \%$ of additional skilled workers are needed to fulfill the needs of the job industry in

Citation: Razali, F. (2021). Exploring Crucial Factors of an Interest in STEM Career Model among Secondary School Students. International Journal of Instruction, 14(2), 385-404. https://doi.org/10.29333/iji.2021.14222a 
the field of STEM to secure a substantial economy of the country. Besides, 5.4 times more technical and scientific careers will be offered from the industry sector than any other field in the future (Blotnicky et al., 2018). Next, the increase of demands for STEM skilled workers was also recorded in Malaysia with a reckoning of 1.3 million skilled workers in the field that are needed to prepare for the industrial revolution (Ministry of Science, Technology, and Innovation, 2015). The need for supplementing this skilled workers' vacancy is getting more demands in the industrial career sector. This event turnout is due to the downturn of science stream students in a consistent trend beginning from secondary level and has influenced the participation of students in the STEM field in Public Higher Learning Institutions (Bell, 2016). STEM career-related knowledge is well-connected with students' knowledge and STEM careers, receiving different students' knowledge based on the consistency of information from the school community regarding STEM careers (Compeau, 2016). Thus, the level of STEM career knowledge that a student has will directly influence a student's interest in pursuing a future STEM career.

Therefore, the reinforcement of the science curriculum in Malaysia with STEM is one of the core initiatives of the Malaysia Education Blueprint 2013-2025 to prepare learners so that they will be able to compete and face the economic revolution of the country. From the aspect of science curriculum implementation, the Ministry of Education Malaysia (MOE) has taken a few steps in which one of them is, expanding the view of learners towards the contents in the science curriculum for life as well as improving the skills in the field of science and technology (National Science Academy, 2016; MOE, 2015). Also, STEM education is required to develop 21st-century skills in every STEM subject (Bybee, 2010). The skills developed as a result of STEM learning encompass the entire 21 st-century skills of creativity, critical thinking, collaboration, and innovation based on STEM knowledge (Banks \& Barlex, 2014; Daugherty, 2009). The incorporation and awareness of STEM is learner-centered whereas teachers act as a facilitator to ease learners' proclivity of interest by relating to science curriculum and STEM during the teaching and learning sessions and as the support (Blankenburg et al., 2016).

\section{STEM Education in a Real World}

Over a decade, STEM has been the topic of discussion in the international education system. Discussions are driven by global economic changes that demand more STEM professionals (Dierking \& Falk, 2016). Early planning is necessary for student preparation in mastering the science curriculum on the importance of future careers. Thus, maintaining and enhancing students 'positive interest in science is an important starting point for students' preparation for STEM careers (Hidayah \& Rohaida, 2014; Gamse et al., 2016; Wyss, Heulskamp, \& Siebert, 2012; Ibrahim, Ayub, Yunus, Mahmud \& Bakar, 2019).

The science curriculum is the driving force toward the development of STEM learning in Malaysia (Curriculum Development Division, 2016). The growth of STEM in our education system has started emphasize on learners at the secondary level to instill awareness on the importance of science and technology for their future needs (English, 
2016; Hidayah \& Rohaida, 2014). Therefore, the purpose of the science curriculum not only to improve the mastery of science and performance among learners at the secondary level but also as the starting point in producing STEM skilled workforce. Thus, learners who lack interest in science is worrying and calls for the invigoration of learners enrolment in the science curriculum as planned so the learners` accomplishment is aligned to the needs of the nation (Dierking \& Falk, 2016; Effandi \& Zanaton, 2009; Liaghatdar, Soltani, \& Abedi, 2011).

Realizing the importance of the science curriculum to develop a country, MOE has taken early approaches to integrating STEM in the secondary school curriculum. This awareness of the importance of the science curriculum is crucial so that learners in the science stream particularly can identify their path and goals after learning and developing clearer goals of their career (Wyss et al., 2012). A significant source of influence for student engagement in science education is the connection with future career aspirations (Osborne and Collins 2000; Cleaves 2005; Jenkins and Nelson 2005). Strong evidence for discoveries regarding students' future career directions, especially science careers, will begin to be successful in the early stages (Bennett, 2003). Moreover, students from the science stream are an important asset to encourage economic equity from the generation of each learner's potential on STEM career development for the upcoming industry. Therefore, the generation of STEM on all students in Malaysia has been implemented gradually by MOE by introducing the Standardized Curriculum for Secondary Schools (SCSS) in the year 2017 which had replaced the Secondary School-Based Curriculum (SSBC) as an early approach in integrating STEM (Curriculum Development Division, 2016).

\section{Students' Needs in STEM Implementation}

The global education system appeals that learners need to focus on STEM to generate continuous mastery of scientific knowledge more meaningfully (Hora \& Oleson, 2017). Therefore, Malaysia has taken a progressive step to strengthen STEM in the education system to ensure the development of the nation's economy is always supported by quality skilled workers.

The Malaysia Education Blueprint has outlined a few steps to prepare learners by integrating STEM in teaching and learning. Among the steps highlighted are emphasize in increasing learners' interest in STEM through refining the science curriculum (MOE, 2013). The strengthening of the science curriculum and STEM to fulfill the needs in the learning environment can help support the development of learners' career interests.

Previous studies (English, 2016; Han, 2015; Kamisah \& Marimuthu, 2010; Micari, Van Winkle, \& Pazos, 2016) showed that the implementation of STEM in the science curriculum is evident when learners get the clear picture on the importance of STEM for their career needs. For this reason, fulfilling the learning needs with awareness on the knowledge of science for the future gives a positive influence towards learners' accomplishments especially with needs of the learning process that is entailed to attitudes on STEM (Badri et al., 2016), science motivation (Wang \& Degol, 2013) and the strengthening of $21^{\text {st }}$ century skills (Wah Chu et al., 2017) as well as inclusivity of 
parents' involvement (Rozek et al., 2017; Din, Ayub, \& Tarmizi, 2016) on the formation of learners' STEM career interest. Thus, the science curriculum initiative to instill STEM in the Malaysian education system is a crucial effort that encompasses knowledge, skills, and the formation of interest in STEM fields to increase the number of skilled workers to stimulate the economy of the nation.

\section{Attitudes towards STEM}

Establishing a positive attitude toward STEM starting at the high school level will impact the momentum of students in choosing STEM careers (Unfried et al., 2015).The inculcation of positive attitudes towards STEM beginning from secondary school level has given an impact on the learners' momentum in choosing STEM careers (Unfried et al., 2015). There are varying definitions used by researchers to define learners' attitudes in the learning process. Each researcher defines attitudes based on the different psychological backgrounds as the foundation to conclude the definition. Attitude is defined as the inclination to respond to surrounding factors within the learners' environment (Ardies, De Maeyer, Gijbels, \& Van Keulen, 2014).

The attitudes towards STEM is the stimulation of knowledge from the concept of science, technology, engineering and mathematics driven with the knowledge of STEM profession that is evident for the needs of future careers (Tseng et al., 2013). Moreover, as argued by Ricks (2006) understanding the concept of science and math in real-life situations will give an impact on learners' attitudes towards science and math which indirectly assist in forming their STEM career interest. Learners need reinforcement of each STEM element so that it could influence the momentum of learners' attitudes to continuously explore STEM to garner their interest for the career.

\section{Parental Authority}

Parental authority is defined as the social relationship that exists between parents and students by integrating knowledge and skills to build social capital that can provide positive input for the future (Buri, 2013). Parents who have early awareness of the importance of global market value in STEM will see the importance of STEM not only from the perspective of mastery to knowledge but also from different perspectives which are, its importance towards the development of learners' interest towards STEM career at the initial stage. Concerned parents on the learning and paths of learners will give a direct positive influence on the development of interest to fulfill the learners' career aspirations (Eisner, 1979). Parents are crucial assets in the academic development and learners' readiness in the career world. The previous study by (Davis, 2005) asserts that parents are a significant factor in learners' career development beginning from secondary until the choosing stage of their field of education in Higher Learning Institutions. Therefore, parents' awareness of the market value of STEM careers for the future has given us a reflection of learners' STEM career interest development towards.

The influence of parents on the reinforcement of STEM among learners is like a continuous-time, always needed to produce quality products for a lifelong industrial need. National Research Council Washington (2015) supports the statement by saying that the learning model of STEM introduced was based on current updates (Figure 1). 
This is done by emphasizing the direct influence of parents along with the mediator influence through the values of career demands of the STEM industry in the learners' life. Therefore, learning needs with the awareness of the value in STEM start from home and is a dynamic effort towards the success of learners in preparing themselves for the STEM industry careers in the future.

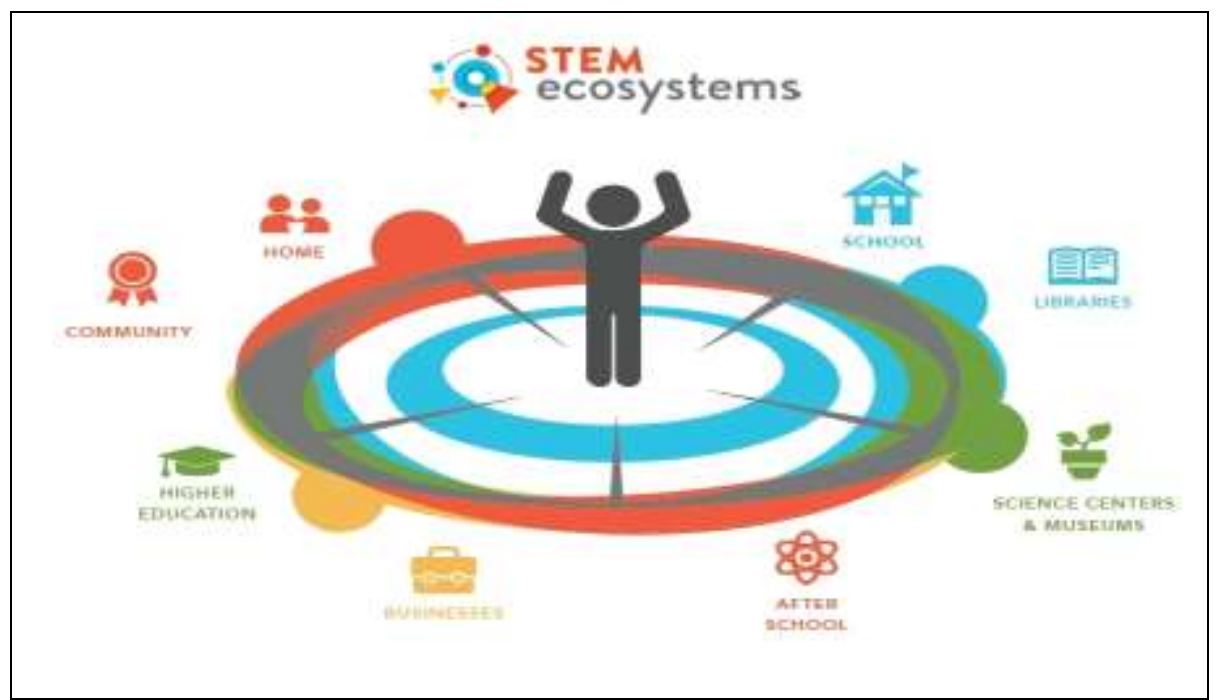

Figure 1

STEM learning ecosystem

Source: Adapted from National Research Council Washington (2015)

\section{$21^{\text {st }}$ Century Skills}

STEM in the education system offers meaningful learning by giving the space for learners to apply the concepts from different skills that are multidisciplinary to solve the problems which are known as the $21^{\text {st }}$ century skills (Lilia Halim, 2018). The $21^{\text {st }}$ century skills are learners' skill that are important for their career needs which encompass learning skill (critical thinking, collaborative, creativity and communication), literacy skill (information, media and technology) and life skill (leadership and productivity) (Kaufman, 2013). The $21^{\text {st }}$ century skills for the preparation of learners to fill in the STEM career needs is an important mission in the education system across the nation. The demands of the STEM industry are not merely limited to graduates who excel academically, but also competently in 21 st Century Skills with priorities towards the career industry (Wah Chu et al., 2017).

Moreover, intellectual learners are also measured based on the skills they use in helping the community to make decisions and are evaluated critically to produce products that are of better qualities (Nurnadiah, Evi, \& Kamisah, 2014). Therefore, the importance of 21 st Century Skills must be given full attention so that the mastery of knowledge is analogous to the strengthening of 21 st Century Skills that is a complete package to 
produce skilled professional workforce who are able to solve problems involving social issues as the fundamental pavement to global industry.

\section{Motivation towards Science}

Motivation towards science refers to the way students think about themselves by taking into account students' preparation for self-directed learning processes and activities and student consistency towards more focused learning in sceince (Hora \& Oleson, 2017). Motivation influences the development of learner STEM career interest. Motivations towards science gives an influencing effect proportionately to the development of learners' STEM career interest (Razali, Manaf, Othman, \& Hassan, 2020; Mohd Ayub, Tarmizi, Abu Bakar, \& Luan, 2014). Thus, the importance of motivation will always be the main thing to fulfill the learning needs in the teaching and learning process to achieve the intended curriculum goal. For this reason, a high motivation will not only assist learners in learning but also this motivation level will influence learners to value the learned science curriculum and drive them towards developing interest in their future careers (Beerenwinkel \& von Arx, 2016). Therefore, the motivation in learning science is needed especially for learners in the science stream to ensure that they could utilize all their science knowledge capacity which they have learned to pave interest towards STEM careers that match the development of the learners' proclivity.

\section{STEM Career}

STEM careers can strengthen the country's economy to prepare to meet the challenges of the career industry by meeting the growing demands of skilled labor until 2022 for the strengthening of the country's economy. Among the career prospects in STEM fields that have a high impact on economic change such as information technology, engineering, agriculture, geology, scientists, health, environment, and aerospace (Badri et al., 2016). In line with the New Economic Model of Malaysia emphasizing the important aspects are high income to dominate and compete with developed countries starting in 2020 (Figure 2). Accordingly, the need for skilled labor to meet the target for the annual income of the people in comparison to the developed countries is of US $\$$ 15,000 to US $\$ 20,000$. Therefore, the awareness of improving the economy of the country is the responsibility of all the people and needs to be formed early during the schooling period so that Malaysia can provide skilled labor that is competitive with high-income countries. 


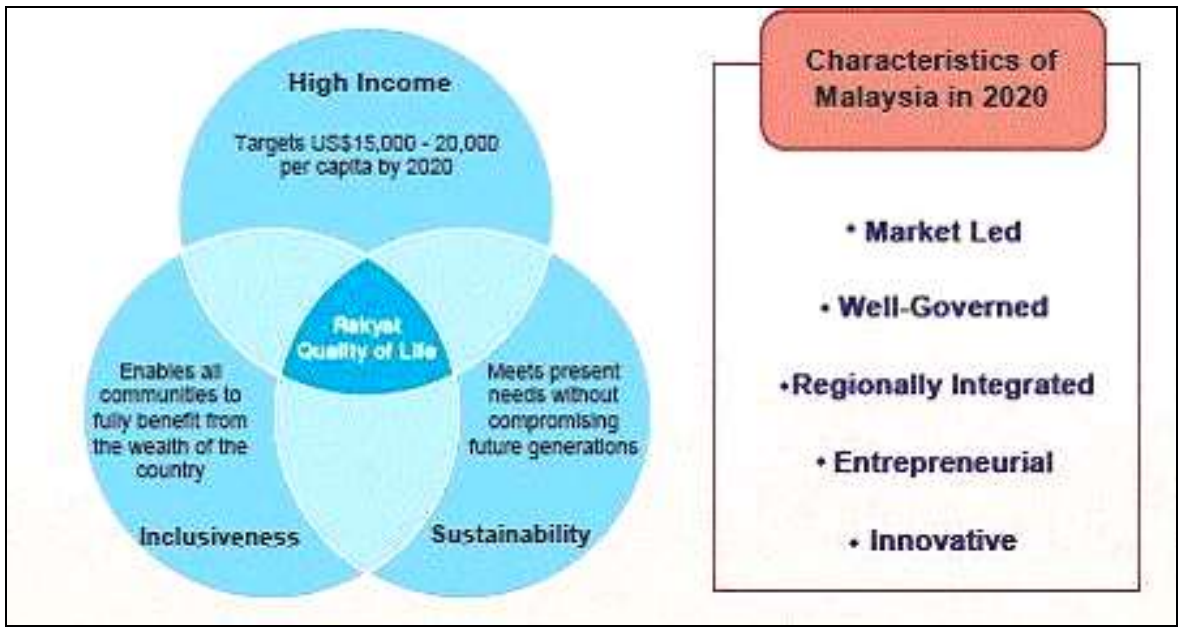

Figure 2

Malaysia new economy model in 2020

Source: National Economic Advisory Council (2010)

Typically, a country's progress starts with the education system (Fayer et al., 2017). As such, the development of the Malaysian education system is always supported by the innovations implemented in the science and STEM curriculum to prepare students to be ready to drive the Malaysian economy for the needs of the industrial sector (National Economic Model For Malaysia, 2010). In addition, a country's economic development depends on the science and STEM curriculum to provide a more comprehensive STEM career platform for students (Asunda, 2014; Nugent et al., 2015; Zeynep, Dokme, \& Unlu, 2016). Therefore, to remain competitive globally, Malaysia needs to prove that the success of the education system can provide skilled labor as a human capital to the country in science, technology and engineering to meet the needs of the STEM career industry (Lilia Halim, 2018).

Therefore, the study was conducted to identify factors that influence students' STEM careers. Factors are significant student needs that have been proven from previous studies to influence students' STEM careers directly. The study also provides a new approach by collecting factors from students' needs in the form of direct and indirect models.

\section{METHOD}

This research is quantitative and shows a form of correlation by studying the influence between independent variables and dependent variables. The approach used in this research are questionnaires to study the influence of attitudes towards STEM, $21^{\text {st }}$ century skills, science motivation, and parental authority among learners in the science stream on the formation of STEM career interest. This study involves the designing of models on direct influence from an independent variable which are attitudes towards 
STEM and parental authority among learners in the science stream on the formation of STEM career interest. The approach to this study is to develop a model on the direct influence of the independent variables towards STEM and parental authority including two variables for the mediator influence which are science motivation and $21^{\text {st }}$ century skills towards the formation of STEM career interest among learners.

This study was conducted in a daily secondary school and was randomly chosen in the state of Selangor. The random sampling of schools is based on the ten districts in Selangor, Malaysia. The sampling of 314 Form 4 students using the Stratified Random Sampling method. In addition, according to Shumacker and Lomax (2004), the sample size for SEM analysis is 250 to 400 . Therefore, the study with a sample size of 314 achieved an appropriate sample size with estimated structural equation modeling so that the model could work well and reach index appropriateness.

Permission of three instruments are used in this study to represent each variable which has been approved for adaptation based on the research objectives in Table 1.

Table 1

The instruments used to measure the variables

\begin{tabular}{llll}
\hline Instrument & Variables & Reference & Total Item \\
\hline S-STEM and interest & Attitudes (SIKAP) & Unfried et al., & 26 \\
in STEM careers & $21^{\text {st }}$ Century Skills (KAK21) & 2015 & 11 \\
& STEM Career Interest (KERSTEM) & & 12 \\
\hline SMQ-II & Motivation (MOT) & Glynn et al, 2011 & 25 \\
\hline PAQ & Parental influence (AUT) & Buri, 2013 & 10 \\
\hline Total & & & 84 \\
\hline
\end{tabular}

The survey instrument was approved by Unfried et al., (2015), Friday Institute for Educational Innovation, the USA to be standardized and adapted for future studies. According to Unfried et al., (2015) S-STEM instruments are important for measuring the influence of each construct on student participation in science to study students' sustainability in their choice of careers in STEM fields. The instrument represents the independent variable of attitude and $21^{\text {st }}$ century skills to measure the impact of students' STEM career interests.

SMQ II in the study of Chumbley et al., (2015) argues that student motivation and selfefficacy are the most influential constructs for students to develop a motivation to study

science towards STEM careers in agriculture. Meanwhile, results from the SMQ II analysis by Shin et al., (2017) argues that measuring career motivation is an accurate predictor of student choice in the STEM field of higher education. Therefore, this study uses the SMQ II instrument to measure the influence of direct and indirect student science motivation on the formation of STEM science students' interest in the science stream in Malaysia. The instrument represents the independent variable of motivation towards science to measure the influence on students' STEM career interests.

The survey was developed by Buri (2013) based on Baumrind`s 3 Parenting Styles Model (authoritative, permissive and authoritarian). However, the study only focused on 
the dominant parental authority influencing students in career formation based on data analysis results from pilot studies. The instrument represents the independent variable of parental authority to measure the influence on students' STEM career interests. Thus, the research instrument is used as a tool to complete the hypothesis study.

\section{Analysis of Data}

\section{Measurement Model using the Confirmatory Factor Analysis (CFA)}

Structural Equation Modeling (SEM) was used to analyze the influence between attitudes towards STEM, parental authority, science motivation and $21^{\text {st }}$ century skills on the STEM career interest. In this study, there are two approaches in modelling used; firstly, the researcher tested the measurement model using the data from the pilot study and secondly, the researcher continues to the next analyzing procedure which is the complete structural model where if the model developed has achieved the fit index and is accepted (Kline, 2011). This section will report the findings gathered from the measurement model.

CFA is a statistical method to determine the relationship between constructs or latent variables and the indicators involved in the study (Byrne, 2010). In research, CFA's function is to determine the model fit index through field study (Table 3). However, there are no consensus among researches about the indexes that are needed to be used more specifically (Zainuddin, 2015). Therefore, Hair et al. (2010) recommends the use of indexes with a minimum of one fit index model which are absolute fit, incremental fit and parsimonious fit categories (Table 2).

Table 2

Model Fit Index suggested by Hair et. al. (2010)

\begin{tabular}{lllll}
\hline Category & $\begin{array}{l}\text { Names } \\
\text { of Index }\end{array}$ & Complete Names of Index & $\begin{array}{l}\text { Accepted } \\
\text { Index }\end{array}$ & $\begin{array}{l}\text { Measurement } \\
\text { Model }\end{array}$ \\
\hline Absolute fit & Chisq & Discrepancy Chi-square & $>0.05$ & 3573.622 \\
\hline & RMSEA & $\begin{array}{l}\text { Root Mean Square of Error } \\
\text { Approximation }\end{array}$ & $<0.08$ & 0.043 \\
\hline Incremental fit & AGF & Goodness of Fit Index & $>0.90$ & 0.793 \\
\hline & CFI & Adjusted Goodness of Fit & $>0.90$ & 0.776 \\
\hline & TLI & Tucker-Lewis Index & $>0.90$ & 0.926 \\
\hline Parsimonious fit & Normed Fit Index & $>0.90$ & 0.923 \\
& Chisq/df & $\begin{array}{l}\text { Chi-square/ Degrees of } \\
\text { Freedom }\end{array}$ & $<5.0$ & 1.724 \\
\hline
\end{tabular}

The recommended index and often used by researchers for each of the following categories according to Hair et al., (2010) is absolute fit: RMSEA or GFI, incremental fit: CFI or TLI and parsimonious fit: Chisq/df.

The model which achieved the fit index for absolute fit shows that the model has a superior advantage by showing that the fundamental theories used are suitable for the research data. Whereas the fit index for Incremental fit is also known as a comparative 
or relative index that is suitable with the research data. Finally, the model that achieves the fit index, Parsimonious fit shows that the model has an ideal constructs to measure the dependent variable by fulfilling the fit index value that was predetermined.

Table 2 shows the measurement model for each latent construct involved in this study. The model fulfilled each index category such as P-value, RMSEA, CFI, TLI and Chisq/df in the model.

Generally, the measurement model could fulfill the majority value of the model fit indexes because each category shows the model is good and acceptable (Schreiber, Nora, Stage, Barlow, \& King, 2006). In addition, the study has achieved among the most important index values to measure the fit indexes for the measurement model such as RMSEA, CFI dan Chisq/df for the continuous data (Hu \& Bentler, 1998). Moreover, the study has achieved most of the index values at a minimum of one index for each category determined which are the indexes for the P-value, Chisq, RMSEA, CFI, TLI and Chisq/df based on the continuous data of this study.

The needs of fit indexes to represent three categories are absolute fit which is RMSEA which acts as the measure for covariance fit matrix of the population. One of the indexes which is always the main reference to identify the fit of the model and the sample size. The value of RMSEA index is 0.08 and below which shows that the index has achieved a satisfactory fit for the model and sample size of the study with the index value recorded 0.043. In addition, according to $\mathrm{Hu}$ and Bentler (1998) the lower value of RMSEA shows better criterion value.

The result of the analysis shows that the measurement model has achieved the index value of incremental fit which is CFI to measure the overall index of the model to determine the suitable sample size with the index value of 0.793 . The index value CFI $>0.9$ is important to ensure the design of the study model and sample size also could explain the latent constructs involved with clarity (Hu \& Bentler, 1998). In addition, the index value of CFI exceeding 0.9 is also recognized as a good indication for CFA simultaneously it complies the needs of the fit of the model (Hair et al., 2010). Whereas, the index value of Chisq/df Parsimonious fit category shows that the model has the ideal value to measure the dependent variable by fulfilling the fit index value a the fit of 1.724. The index value of Chisq/df is less than 3.0 shows that the study model was built based on theoretical and fulfills the index statistical analysis excellently (Hair et al., 2010). All in all, the analysis of CFA has achieved three categories which represents the values of RMSEA, CFI and Chisq/df by fulfilling the model fit index.

After the CFA procedure for the measuring model has been completed, the validity and reliability of constructs need to be measured. The results of the findings prove that the measurement model of this study is valid and reliable based on the following procedures:

Unidimensional: it is a process of discarding items that have low factor loading. The process of removing items continued until the fit indexes achieved the desired level required. 
Validity: This was achieved through the following processes: -

I. Convergent Validity: AVE $\geq 0.50$, refer Table 3

II. Construct Validity: All fulfilled the compatibility indexes (fit indexes) model to fulfill the required level of indexes.

III. Discriminant Validity: No overlapping items, discarded or 'free parameter' in nature for all research constructs with the correlational value less than 0.85 , refer Table 4.

Reliability: This was achieved through the following processes:

I. Internal Reliability: Cronbach alpha $\geq .70$ (Table 3 )

II. Composite Reliability (CR): $\mathrm{CR} \geq 0.6$ (Table 3 )

Table 3

Summary of analysis on the confirmatory factors for all latent factors

\begin{tabular}{lllll}
\hline Constructs & Discarded Items & Alpha Cronbach $(>0.7)$ & CR $(\geq 0.6)$ & AVE $(\geq 0.5)$ \\
\hline $\begin{array}{l}\text { Attitudes } \\
\text { towards STEM }\end{array}$ & $\begin{array}{l}\text { S3, S5, S9, S10, } \\
\text { S13 }\end{array}$ & .947 & .97 & .63 \\
\hline $\begin{array}{l}21^{\text {st }} \text { Century } \\
\text { skills }\end{array}$ & KA1, KA4 & .955 & .95 & .70 \\
\hline $\begin{array}{l}\text { Science } \\
\begin{array}{l}\text { Motivation } \\
\text { Parental }\end{array}\end{array}$ & M13, M16, & .956 & .96 & .54 \\
$\begin{array}{l}\text { Authority } \\
\text { STEM career }\end{array}$ & K1, K5, K8, & .807 & .95 & .70 \\
interest & K11, K12 & .953 & .89 & .50 \\
\hline
\end{tabular}

Table 4

Correlation between constructs for the measuring model

\begin{tabular}{llllll}
\hline Constructs & $\begin{array}{l}\text { Attitudes towards } \\
\text { STEM }\end{array}$ & $\begin{array}{l}\text { Parental } \\
\text { Authority }\end{array}$ & $\begin{array}{l}\text { Science } \\
\text { Motivation }\end{array}$ & $\begin{array}{l}21^{\text {st }} \text { Century } \\
\text { Skills }\end{array}$ & $\begin{array}{l}\text { STEM Career } \\
\text { Interest }\end{array}$ \\
\hline $\begin{array}{l}\text { Attitudes towards } \\
\text { STEM }\end{array}$ & $* .793$ & $* * .159$ & $* * .170$ & $* * .222$ & $* * .195$ \\
\hline Parental Authority & $* * .159$ & $* .836$ & $* * .004$ & $* * .828$ & $* * .102$ \\
\hline Science Motivation & $* * .170$ & $* * .004$ & $* .734$ & $* * .033$ & $* * .731$ \\
\hline $21^{\text {st }}$ Century Skills & $* * .222$ & $* * .828$ & $* * .033$ & $* .836$ & $* * .096$ \\
\hline STEM Career Interests & $* * .195$ & $* * .102$ & $* * .731$ & $* * .096$ & $* .707$ \\
\hline
\end{tabular}

* Square root of AVE

** Correlation between constructs $(<.85)$

Table 4 shows the bolded diagonal values referring to the square root of AVE values for each construct. The model achieves discriminant validity with the bolded diagonal values which are higher compared to the other values in lines and columns and these represent the correlational scores for each construct based on the measurement model (Zainuddin, 2015). 


\section{FINDINGS}

The analysis was then continued with structural model testing. In this study, the structural model represents the magnitude and direction of influence among the set of latent variables to enable the researcher to evaluate the proposed model based on the study hypothesis. Testing the structural model using AMOS also can produce some information on the overall effects, the indirect effect and direct effect of the variables are as a result of the findings in the model analysis (Byrne, 2010). This section will report the model fit index for the influence of attitudes towards STEM, parental authority, $21^{\text {st }}$ century skills and science motivation on the formation of STEM career interest among learners. Generally, the research model (Figure 4) has achieved model fit index at a minimum of one index for each category which is a good model and can be accepted (Byrne, 2010; Hair et al., 2010, 2014).

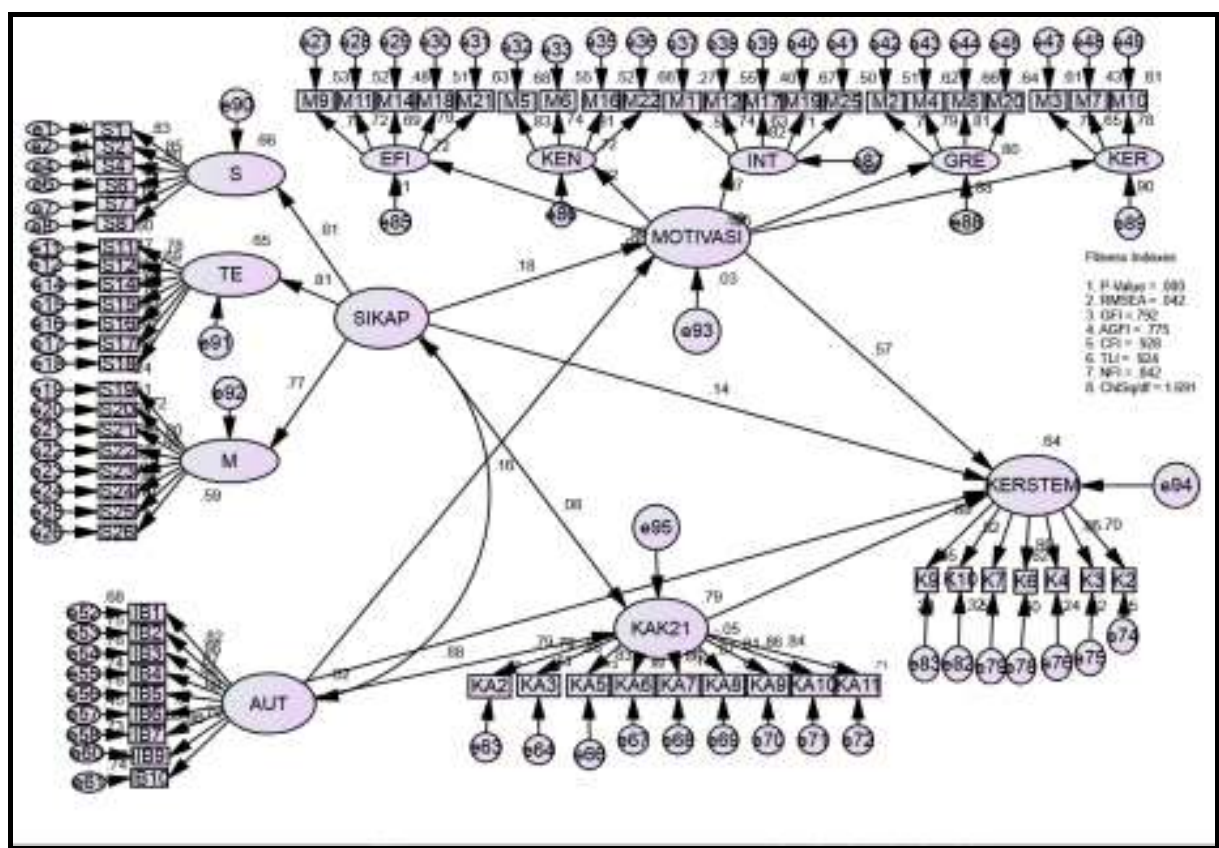

Figure 4

Standard regression weight for this research model

The early step of the hypothesis testing of the proposed model is based on the data of this study to fulfill the fit index model which were predetermined. Each of the variables was tested in graphical form, and each item of significance was retained and vice versa. Further details of the fit indexes for each category are detailed in Table 5. The next step is, in order to determine the direct effect of the exogenous variable, which is the attitude towards STEM, parental authority, $21^{\text {st }}$ century skills (KAK21) and science motivation on the endogenous variable which is the STEM career interest. 
Table 5

Fit indexes for the proposed model

\begin{tabular}{llll}
\hline Category & Name of Index & Accepted Index & Proposed Model Index \\
\hline Absolute fit & Chisq & $>0.05$ & 3545.191 \\
\cline { 2 - 4 } & RMSEA & $<0.08$ & .042 \\
\cline { 2 - 4 } Incremental fit & GFI & $>0.90$ & .792 \\
& AGFI & $>0.90$ & .775 \\
\cline { 2 - 4 } & CFI & $>0.90$ & .928 \\
\cline { 2 - 4 } & TLI & $>0.90$ & .924 \\
\cline { 2 - 4 } & NFI & $>0.90$ & .842 \\
\hline Parsimonious fit & Chisq/df & $<5.0$ & 1.691 \\
\hline
\end{tabular}

Table 5 shows the proposed model has fulfilled the fit model for each category with a minimum of one index value achieved. This finding shows that the proposed model achieved the fit indexes model and has are significant theory.

\section{Determining Coefficient $\left(\mathbf{R}^{2}\right)$ For the Structured Model}

The determining of influence between exogenous and endogenous variance from squared multiple correlations $\left(\mathrm{R}^{2}\right)$ can be explained from the results of structural model analysis. The determining coefficient refers to the value of the overall contribution in this study from the effect of exogenous variables towards the endogenous variables by using SEM (Hair et al., 2010). Therefore, to determine the value of $\mathrm{R}^{2}$ in this study, it is crucial to measure comprehensively on the exogenous influence of the study which are attitudes towards STEM, parental authority, $21^{\text {st }}$ century skills, and science motivation on the formation of STEM career interest among learners more accurately based on a complete structural model.

Table 6

Standardized regression weight for the determination coefficient $\left(\mathrm{R}^{2}\right)$

\begin{tabular}{lll}
\hline Constructs & Estimated Standards & $\mathrm{R}^{2}$ \\
\hline ATTITUDES-> MOTIVATION & .181 & \\
MOTIVATION->KERSTEM & .568 & \\
ATTITUDES->KERSTEM & .145 & \\
AUT-> MOTIVATION & .494 & .636 \\
MOTIVATION->KERSTEM & .568 & \\
AUT->KERSTEM & -.494 & \\
ATTITUDES-> KAK21 & .078 & \\
KAK21->KERSTEM & -.054 & \\
ATTITUDES->KERSTEM & .145 & \\
AUT-> KAK21 & -.876 & \\
KAK21->KERSTEM & -.054 & \\
AUT->KERSTEM & -.494 & \\
\hline
\end{tabular}

\section{DISCUSSION}

The study performed tests to determine the direct effect of each dependent variable on the dependent variable based on the study objective. The first objective of the study was to test model fit indexes from the direct influence of STEM attitudes, parental authority, 
21st century skills and science motivation on the formation of STEM career interests among Form Four science students in Selangor. Based on the theories and past studies, attitudes toward STEM (Badri et al., 2016), parental authority (Nugent et al., 2015; Rozek et al., 2017), 21st-century skills (Unfried et al., 2015) and science-based motivations (Glynn, Taasoobshirazi, \& Brickman, 2009) have a significant direct impact on students' STEM career formation. This study has developed a model that encompasses all the direct and indirect variables that have been proven from previous studies by incorporating elements of theory related to the formation of STEM students' career interests.

The impact of students' STEM career interests can be evidenced by the standardized regression weight $\left(R^{2}\right)$ value of the study model. The value of $R^{2}$ on the impact of intermediaries is discussed which includes attitudes toward STEM, parental authority, 21 st century skills and science motivation in building STEM career interests. However, the size of the effect of the overall influence of the study needs to be determined to see the overall predictions of the study variables accurately for exogenous and endogenous influences. This is because it is possible that part of a single projection analysis of a model has a weak value and cannot measure the impact of the effect accurately but rather strongly and accurately on a model's results when in general (Kline, 2011). Accordingly, the variance value for the overall model suggested that the effect size was .636 or $63.6 \%$ contribution to explain the influence of STEM attitudes, parental authority, 21st century skills and science motivation on the formation of STEM career interests in among science students.

\section{CONCLUSION}

STEM career development models are one way to identify students' interest in STEM careers specifically from statistical testing of STEM attitudes, parental authority, science motivation and 21 st century skills. Not only can researchers determine the variables that influence students 'STEM career interests but researchers can integrate key elements based on learning theory for students' needs to support curriculum innovation in STEM.

The results of the direct analysis showed that STEM attitudes, science motivation and parental authority classified in one model showed significant influence and are in line with previous single-path studies. More comprehensive studies with an emphasis on the integration of variables reported from previous studies have a direct impact on the formation of student career interests. The direct and indirect influence of the study also proves that Malaysian students, especially in Selangor, see the importance of science learning needs in three variables: STEM attitudes, science motivation and parental authority to create interest in STEM students' careers.

Models will be used in generally about STEM goals in the Secondary School Curriculum that does not only focus on student enrollment but also serve as a primary support and encouragement to students in shaping students' interest in STEM careers. Thus, the research model can contribute to the literature or reference especially for science education research in Malaysia. Finally, as evidence in the study of the influence of STEM attitudes, the motivation for science and parental authority on STEM career 
interests is in line with the elements of the selected research theory namely social cognitive theory, self-determination theory, and Eisner curriculum theory and are always needed in the learning process to meet the needs of students and support the results of science learning on the continuity of student readiness to compete for the needs of the career industry.

The study was conducted involving students. Further research by involving teachers as survey respondents can also provide different perspectives on efforts to shape student career interests from approaches such as learning planning, activities, and teacher readiness to implement STEM in teaching. Therefore, the need to diversify research methods and respondents to look at influencing factors at different angles will provide the essence of differentiating STEM career interests among students.

\section{REFERENCES}

Ardies, Maeyer, S., Gijbels, \& Van Keulen, H. (2014). Students attitudes towards technology. International Journal of Technology and Design Education, 25(1), 43-65. http://doi.org/10.100 7/s10798-014-9268-x

Asunda, P. A. (2014). A conceptual framework for STEM integration into curriculum through career and technical education. Journal of STEM Teacher Education, 49(1), 4567.

Badri, Alnuaimi, A., Mohaidat, J., Al Rashedi, A., Yang, G., \& Al Mazroui, K. (2016). My science class and expected career choices-a structural equation model of determinants involving Abu Dhabi high school students. International Journal of STEM Education, 3(1), 35-47. http://doi.org/10.1186/s40594-016-0045-0

Bahri, N. M., Suyawati, E., \& Osman, K. (2014). Students' Biotechnology Literacy: The pillars of STEM education in. Eurasia Journal of Mathematics, Science \& Technology Education, 10(3), 195-207. http://doi.org/10.12973/eurasia.2014.1074a

Banks, F., \& Barlex, D. (2014). Teaching STEM in the secondary school: Helping teachers meet the challenge. Abingdon: Routledge.

Beerenwinkel, A., \& Von Arx, M. (2016). Constructivism in practice: An exploratory study of teaching patterns and student motivation in physics classrooms in Finland, Germany and Switzerland. Research in Science Education, 78(8), 1-19. http://doi.org/10.1007/s11165-015-9497-3

Bennett, J., \& Hogarth, S. (2005). Would you want to talk to a scientist at a party? Students' attitudes to school science and science. York: University of York, Department of Educational Studies.

Blankenburg, J. S., Höffler, T. N., \& Parchmann, I. (2016). Fostering today what is needed tomorrow: Investigating students' interest in science. Science Education, 100(2), 364-391. http://doi.org/10.1002/sce.21204 
Blotnicky, K.A., Franz-Odendaal, T., French, F. et al. (2018). A study of the correlation between STEM career knowledge, mathematics self-efficacy, career interests, and career activities on the likelihood of pursuing a STEM career among middle school students. $I J$ STEM Ed 5, 22. https://doi.org/10.1186/s40594-018-0118-3

Buri, J. R. (2013). An instrument for the measurement of parental authority prototypes. Journal of Chemical Information and Modeling, 53(8), 1689-1699. http://doi.org/10.1017/CBO9781107415324.004

Bybee, R. (2010). What is STEM education? Science, 329(5995), 996.

Byrne, B. (2010). Structural equation modeling with AMOS: Basic concepts, applications, and programming (2nd Edition). New York: Taylor \& Francis Group. Retrieved from http://www.taylorandfrancis.com

Chumbley, S. B., Haynes, J. C., \& Stofer, K. A. (2015). A measure of students' motivation to learn science through agricultural stem emphasis. Journal of Agricultural Education, 56(4), 107-122. http://doi.org/10.5032/jae.2015.04107

Cleaves, A. (2005). The formation of science choices in secondary school. International Journal of Science Education, 27(4), 471-486.

Compeau, S. (2016). The calling of an engineer: High school students' perceptions of engineering. Retrieved from http://qspace.library.queensu.ca/jspui/handle/1974/13924

Curriculum Development Division. Guide to implementing Science, Technology, Engineering and Mathematics (STEM) in teaching and learning (2016). Ministry of Education Malaysia: Malaysia.

Davis, P. E. (2005). The influence of parent education and family income on child achievement: the indirect role of parental expectations and the home environment. Journal of Family Psychology, 19(2), 294-304. http://doi.org/10.1037/08933200.19.2.294

Daugherty, M. K. (2009). The "T" and "E" in STEM. In ITEEA (Ed.). In The overlooked STEM imperatives: Technology and engineering (pp. 18-25). Reston: ITEEA.

Deci, E. L., Olafsen, A. H., \& Ryan, R. M. (2017). Self-determination theory in work organizations: The state of a science. Annual Review of Organizational Psychology and Organizational Behavior, 4(7), 19-43

Deming, D.J., \& Noray, K. (2018). STEM careers and technological change. Harvard University

Dierking, L. D., \& Falk, J. H. (2016). 2020 Vision: Envisioning a new generation of STEM learning research. Cultural Studies of Science Education, 11(1), 1-10. http://doi.org/10.1007/s11422-015-9713-5 
Din, N.M., Ayub, A.F.M., Tarmizi, R.A. (2016). Influence of parental involvement and peer support on mathematics engagement among malaysian secondary school students. Malaysian Journal of Mathematical Sciences 10, 175-185

Eisner, E. W. (1979). The Three Curicula That All Schools Teach: InThe Educational Imagination (Third ed.), pp. 87-107. New York: Macmillian Publishing.

English, L. D. (2016). STEM education K-12: Perspectives on integration. International Journal of STEM Education, 3(1). http://doi.org/10.1186/s40594-016-0036-1

Fadzil, H. M. \& Saat, R. M. (2014). Enhancing STEM education during school transition: Bridging the gap in science manipulative skills. Eurasia Journal of Mathematics, Science and Technology Education, 10(3), 209-218. http://doi.org/10.12973/ eurasia.2014.1071a

Fayer, S., Lacey, A., \& Watson, A. (2017). STEM Occupations: Past, present, and future. U.S. Bureau of Labor Statistics

Gamse, B. C., Martinez, A., \& Bozzi, L. (2016). Calling STEM experts: How can experts contribute to students' increased STEM engagement? International Journal of Science Education, 13(4), 1-18. http://doi.org/10.1080/21548455.2016.1173262

Glynn, S. M., Brickman, P., Armstrong, N., \& Taasoobshirazi, G. (2011). Science motivation questionnaire II: Validation with science majors and nonscience majors. Journal of Research in Science Teaching, 48(10), 1159-1176. http://doi.org/10.1002/tea.20442

Hair, J., Black, W. C., Babin, B. J., \& Anderson, R. E. (2010). Multivariate data analysis (7th ed.). Pearson Prentice Hall.

Hair, J., Gabriel, M., \& Patel, V. (2014). Amos covariance-based structural equation modeling (CB-SEM): Guidelines on its application as a marketing research tool. Brazilian Journal of Marketing, 13(2), 44-55. http://doi.org/10.5585/remark.v13i2.2718

Halim, L. (2018). STEM education: Issues and way forward, STEM education in Malaysia (pp.37-58). Department of Higher Education, Ministry of Higher Education: Malaysia.

Hora, M. T., \& Oleson, A. K. (2017). Examining study habits in undergraduate STEM courses from a situative perspective. International Journal of STEM Education, 4(1): 119. http://doi.org/10.1186/s40594-017-0055-6

Hu, L., \& Bentler, P. M. (1998). Fit indices in covariance structure modelling: sensitivity to under parameterized model misspecification. Psychological Methods, 3(4), $424-453$. 
Ibrahim, N.N. Ayub, A.F.M. Yunus, A.S.M. Mahmud, R. Bakar, K.A. (2019). Effects of higher-order thinking module approach on pupils' performance at primary rural school. Malaysian Journal of Mathematical Sciences, 13 (2), 211-229

Jenkins, E. W., \& Nelson, N. W. (2005). Important but not for me: Students' attitudes towards secondary school science in England. Research in Science and Technological Education, 23(1), 41-57.

Kaufman, K. J. (2013). 21 ways to 21st century skills: Why students need them and ideas for practical implementation. Kappa Delta Pi Record, 49(2), 78-83. http://doi.org/10.1080/00228958.2013.786594

Kline, R. B. (2011). Principles and practice of structural equation modeling. New York: Guillford Press. (Vol. 156).

Liaghatdar, M. J., Soltani, A., \& Abedi, A. (2011). A validity study of attitudes toward science scale among iranian secondary school students. International Education Studies, 4(4), 36-47. http://doi.org/ 10.5539/ies. v4n4p36

Micari, M., Van Winkle, Z., \& Pazos, P. (2016). Among friends: the role of academicpreparedness diversity in individual performance within a small-group STEM learning environment. International Journal of Science Education, 38(12), 1904-1922. http://doi.org/10. 1080/09500693.2016.1218091

Ministry of Education Malaysia. Annual Report 2015 Malaysia Education Blueprint 2013-2025 (2015): Malaysia.

Mohd Ayub, A.F., Tarmizi, R.A., Abu Bakar, K., Luan, W.S. (2014). Adoption of WxMaxima software in the classroom: Effect on students' motivation and learning of mathematics. Malaysian Journal of Mathematical Sciences 8(2), 311-323

New Economic Model for Malaysia (2010). National economic advisory council: Kuala Lumpur.

Nugent, G., Barker, B., Welch, G., Grandgenett, N., Wu, C., \& Nelson, C. (2015). A model of factors contributing to STEM learning and career orientation. International Journal of Science Education, 37(7), 1-22. http://doi.org/10.1080/09500693.2015. 1017863

Osborne, J., \& Collins, S. (2000). Students' and parents' views of the school science curriculum. London: King's College London.

Osman, K. \& Marimuthu, N. (2010). Setting new learning targets for the 21st century science education in Malaysia. Procedia - Social and Behavioral Sciences, 2(2), $3737-$ 3741. http://doi.org/10.1016/j.sbspro. 2010.03.581

Pelan Pembangunan Pendidikan Malaysia 2013 - 2025 (2013). Kementerian Pelajaran Malaysia: Malaysia (Vol. 27). 
Razali, F., Manaf, U.K., Talib, O., \& Hassan, S.A. (2020). Motivation to learn science as a mediator between attitude towards STEM and the development of stem career aspiration among secondary school students. Universal Journal of Educational Research, 8, 138-146.

Ricks, M. (2006). A study of the impact of an informal science education program on middle school students' science knowledge, science attitude, stem high school and college course selections, and career decisions. The University of Texas, Austin.

Rozek, C. S., Svoboda, R. C., Harackiewicz, J. M., Hulleman, C. S., \& Hyde, J. S. (2017). Utility-value intervention with parents increases students' STEM preparation and career pursuit. Psychological and Cognitive Science, 114(5), 77-87 http://doi.org/10.1073/pnas.1607386114

Secondary School Curriculum Standard Handbook (2016). Curriculum Development Division. Ministry of Education: Malaysia.

Schumacker, R. E., Lomax, R. G., \& Group, F. (2010). A Beginner's guide to: structural equation modeling third edition (Third Edit). New York: Routledge Taylor \& Francis Group.

Tseng, K., Chang, C., Lou, S., \& Chen, W. (2013). Attitudes towards science, technology, engineering and mathematics (STEM) in a project-based learning (PjBL) environment. International Journal of Technology and Design Education, 23(1), 87102. http://doi.org/10. 1007/s10798-011-9160-x

Unfried, A., Faber, M., Stanhope, D. S., \& Wiebe, E. (2015). The development and validation of a measure of student attitudes toward science, technology, engineering, and math (S-STEM). Journal of Psychoeducational Assessment, 33(7), 622-639. http://doi.org/ 10.1177/0734282915571160

Wah Chu, S., Reynolds, R., Tavares, N., Notari, M., \& Yi Lee, C. (2017). Twenty-first century skills and global education roadmaps. 21st century skills development through inquiry-based learning, 24(13), 17-32. http://doi.org/10.1007/978-981-10-2481-8

Wang, \& Degol, J. (2013). Motivational pathways to STEM career choices: Using expectancy-value perspective to understand individual and gender differences in STEM fields. Elsevier, 33(4), 304-340. http://doi.org/10.1016/j.dr.2013.08.001

Wyss, V. L., Heulskamp, D., \& Siebert, C. J. (2012). Increasing middle school student interest in STEM careers with videos of scientists. International Journal of Environmental \& Science Education, 7(4), 501-522.

Yearly Report (2016). National Academy of Sciences. Malaysia.

Zainudin Awang. (2015). Structural equation modeling using AMOS. Bandar Baru Bangi Selangor: MPWS Rich Publication. 
Zakaria, E. \& Iksan, Z. (2009). Promoting cooperative learning in science and mathematics education: A malaysian perspective. Eurasia Journal of Mathematics, Science \& Technology Education, 3(1), 35-39

Zeynep, K. U., Dokme, I., \& Unlu, V. (2016). Adaptation of the Science, Technology, Engineering, and Mathematics career interest survey (STEM-CIS) into Turkish. Eurasian Journal of Educational Research, 7(63), 21-38 